\title{
SYSTEMATIC BIBLIOMETRIC REVIEW OF ARTIFICIAL INTELLIGENCE TECHNOLOGY IN ORGANIZATIONAL MANAGEMENT, DEVELOPMENT, CHANGE AND CULTURE
}

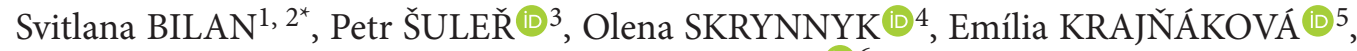 \\ Tetyana VASILYEVA ${ }^{10} 6$ \\ ${ }^{1}$ Faculty of Management, Rzeszow University of Technology, Rzeszow, Poland \\ ${ }^{2}$ National University of Water and Environmental Engineering, Rivne, Ukraine \\ ${ }^{3}$ Institute of Technology and Business in České Budějovice, School of Expertness and Valuation, \\ České Budějovice, Czech Republic \\ ${ }^{4}$ Sumy State University, Sumy, Ukraine \\ ${ }^{5}$ Department of Management and Human Resources Development, Alexander Dubcek University in Trencin, \\ 91150 Trencin, Slovakia \\ ${ }^{6}$ Balatskyi Academic and Research Institute of Finance, Economy and Management, \\ Sumy State University, Sumy, Ukraine
}

Received 18 July 2020; accepted 10 May 2021

\begin{abstract}
Even now, in the times of advanced digitization, the planning and implementation of many organizational measures remain human-driven. Corresponding to a global trend of application of artificial intelligence in all areas of life, it has received more attention in the last few years and garnered emerging clusters of research in usage of this technology for organizational issues. Some companies already offer tools that support different management tasks in the area of organizational development, but they are not holistic. According to the google trend analysis of the search for artificial intelligence, the inquiry to this topic continues increasing.

The purpose of the described investigation was to identify the academic trends in research interaction between such scientific fields, as Artificial Intelligence, Organizational Management, Organizational Development, Organizational Change, and Organizational Culture using bibliometric and network publication analysis. In order to achieve this purpose, we systematically analysed 191 publications between 1983 and 2020 as well as cited and citing publications. The findings of this study provide important conclusions of the current research state. The insightful results are presented in the form of critical review and frame the body of knowledge.
\end{abstract}

Keywords: organizational management, organizational development, organizational change, organizational culture, artificial intelligence, neural network, bibliometric analysis, network analysis.

JEL Classification: D200, D230.

\section{Introduction}

The dynamics of bifurceral transformations in the economy and society change scientific interests in various directions. This thesis is confirmed by investigations of Bilan et al. (2019a), Lyeonov and Liuta (2016), Vasilyeva et al. (2019).

The latest insights from academic analyses show increased organizational interests in various fields. Numerous publications, by Glonti et al. (2020), Lušňáková et al. (2019), Nunes et al. (2018), Savytska et al. (2019), Thabhiranrak and Jermsittiparsert (2019), Vasilieva et al. (2017),
Wysokińśka-Senkus (2020), Yevdokimova et al. (2019) highlight the topic of sustainable development. Adámek (2018), Hammerström et al. (2019), Myroshnychenko et al. (2019) investigate corporate social responsibility. Pham et al. (2019) explore greening. Egerová and Nosková (2019), Hasan (2018), Kowo et al. (2020), Mihalčová et al. (2018), Minasyan and Tovmasyan (2020), Sirbu and Simion (2018), Utami et al. (2019) research diversity aspects. Oladimeji and Udosen (2019) explore the influence of diversification. Idzikowski and Perechuda (2018), Mihardjo and Sasmoko (2019), Polyanska et al. (2019),

*Corresponding author. E-mail: s.bilan@prz.edu.pl 
Žitkienè and Deksnys (2018) focus their research on agility. Atkociuniene and Mikalauskiene (2019), Madani and Rungsrisawat (2019), Skačkauskienè et al. (2018) concentrate their academic activities on knowledge management. Bilorus (2018), Borisova et al. (2020), Khan (2018), Lee and Lee (2018), Machova et al. (2018), Rachida (2020), Stacho et al. (2019), Tielietov and Letunovska (2014) search for new perspectives on human resources management. Kendiukhov and Tvaronaviciene (2017), Peresadko et al. (2014), Zakharkina (2009); Zakharkin (2014), Zakharkin et al. (2019), Zakharkin and Zakharkina (2014) determine innovation as the scope of the present investigations. In addition, the factors that have direct or indirect influence on the qualitative or quantitative organizational performance and characteristics are under consideration. The series of authors demonstrate the importance of different forms of leadership: Nguyen and Luu (2019) emphasize transformational leadership and Suyono et al. (2020) the co-production. Akpoviroro et al. (2019) underline the correlation with strategy. Other aspects are also of great importance in academic publications with regard to topicality. So Hrytsenko and Isayeva (2011), Karpishchenko et al. (2014), Lyulyov and Shvindina (2017), Mikelsone et al. (2020), Pakhnenko et al. (2018), Žitkiené and Deksnys (2018) point out the roles of different aspects of management. Hadbaa and Boutti (2019), Hong-Ngam (2018), Kaasa (2019), Pudjiarti and Hutomo (2020), Titko et al. (2020) in their researches cover important employee aspects.

Other economic and business sectors also gain in significance: Serhii et al. (2014), Syhyda (2013), Teletov et al. (2019), Vasilieva et al. (2017) consider the new methods and tools of marketing. Bilan et al. (2018), Grytsenko et al. (2009; 2010), Ryabenkov and Vasyliyeva (2013), Skliar and Samoilikova (2014), Kvitka et al. (2019) estimate the financial controlling, risks, and tax competition. Shvindina (2019) investigates coopetition as a form of cooperation between competing companies. Enterprise development also remains an important scientific object: Grenčíková et al. (2019) research this topic in general, Bondar et al. (2015) focus on machine building enterprises, Bilan et al. (2019d) consider in this context the institutional complementarity, Olefirenko et al. (2014) offer the approach to technological and technical development estimation. These aspects gain in importance especially when new technological trends are considered. Good examples of such researches are provided by Bilan et al. (2019b, 2019c).

Implementation or support of business processes through artificial intelligence technologies is not new, but it become more important as can be seen from the current researches for example by Giebe et al. (2019) and Njegovanović (2018). Among the trend management technologies that matured from a field of informational technologies, artificial intelligence for the area of organizational management, development, change, and culture is still in the emerging. The selection of the research topic on the technology of artificial intelligence for organizational management results from the intention to thoroughly investigate all scientific publications on concepts and studies in this area to get a scientific overview. For this purpose, the level of organization management as well as the related organizational development, change and culture was considered.

The field of informational technologies for the organization has been growing for at least 50 years. In the past years, some literature reviews have been conducted on the issue of organization, its members and leadership with a view to the widespread use of digital technologies. The reviews are results of systematic analyses of overarching or detailed issues of this topic. The general information captures the global corporate level with the organization and its processes as one of the many components of the respective overview by Senyo et al. (2019). Nevertheless, some bibliometrics, for example Fryk and Iveroth (2009) partially but very precisely performed the source review on the subject of IT in general for organizational change. Each study has provided insight into the topical areas. However, the additional analysis of the aspect of artificial intelligence for organizational management, development, change and culture using rigorous bibliometric tools can provide further insights not previously considered this new technology in the context.

The purpose of this paper is to fill the knowledge gap in the research of usage of artificial intelligence for organizational management, development, change, and culture by detecting and pointing out gaps in the scientific literature and providing an overall direction of research and future research directions.

Scientific work requires continuous bibliometric tracking of recent literary sources. Thanks to new bibliometric tools, the search, collection, sorting, comparison and storage of the most important sources are possible without additional effort. The inspiration for the design of a literary analysis originated from the articles by Kosch and Szarucki (2020), Strielkowski and Chigisheva (2018).

In this article, we present the results of the bibliometric and network analyses from January 2020.

\section{Problem definition}

The main objective of this structured literature analysis was to investigate the topic of artificial intelligence and organizational development regarding organizational management and corporate culture to gain insights into the state of development and perspectives.

The first publications on the use of information technologies in corporate organizations as the strategic practices date back to the early 1970s and was written by Kashyap (1972). The development of the technologies has driven a number of publications dramatically. In 1991, more than 1000 publications were published. The relevance of the topic remains comparatively constant over these years and varies from year to year by a few hundred publications. In comparison, the development of scientific work on the subject of artificial intelligence for organizational development is not consistent. As seen from our 
investigation, the number of publications in this field has risen in the last two years.

The usage of artificial intelligence in organizational management can be diverse. Accordingly, scientists have researched the applying of this technology for decision making, management in general, improvement of the characteristics of special groups as well as direct or indirect influence on organizational management through diversely focused use of artificial intelligence or using its methods. It is interesting to note that the most researched interactions are in the fields of Computer Science and Engineering. Some of these articles are oriented on the increasing the effectiveness of the work or mental performance of employees others are investigated the development of an organizational system in general. Similar fields of science were explored in the study of organizational change and artificial intelligence.

\section{Research methodology and initial data statistic}

The procedure that was used for this research can be represented as the scheme on the Figure 1.

We started the analysis of publications with initial data collection through the search with defined terms. The search results were filtered. The refined results were used for further bibliometric and network analysis.

The main aim of the bibliometric analysis is the prioritization of publications by applying quantity measurement methods. As usual, it investigates the number of publications in the defined topic, their authors (scientists) and scientific institutions. It was also applied for evaluation of such parameters as the year of publication, subject area, document type, source type and title, keywords, affiliation, and country. Based on this analysis, the results of our bibliometric analysis were visualized as lists, tables, maps, diagrams, networks.

Compared to the bibliometric analysis, that evaluates quantitative data, the network analysis provides the qualitative scientific explorations with the focus on publication correlations and their impact in the network. In the network analysis, not the publications, but their citations, keywords, terms in the titles were appraised.

Some simple tools were used for bibliometric and network analysis. We performed an initial search in the Scopus database to collect the publications. The newest version of Scopus has integrated analysis mechanisms for bibliometric analysis. We compared the filtered results in the Scopus with those imported into Zotero (EndNote) and came to the same results. This knowledge allowed us to continue to use the analysis tools from Scopus for the visualization of filtered results. The results of investigations have been immediately visualized in the form of lists and diagrams. These are very useful for illustrating the details of simple bibliometric searches. Conversely, for the network analysis, some other tools are required. For our investigation, we used visualization tools Gephi and VOS Viewer. VOS Viewer, as a tool for effective clustering visualization, was used for network presentation of keyword correlations (Van Eck \& Waltman, 2017a, 2017b). Gephi is a proven tool for network citation analysis (Cherven, 2015).

The following sections describe the procedure and results of bibliometric and network analysis.

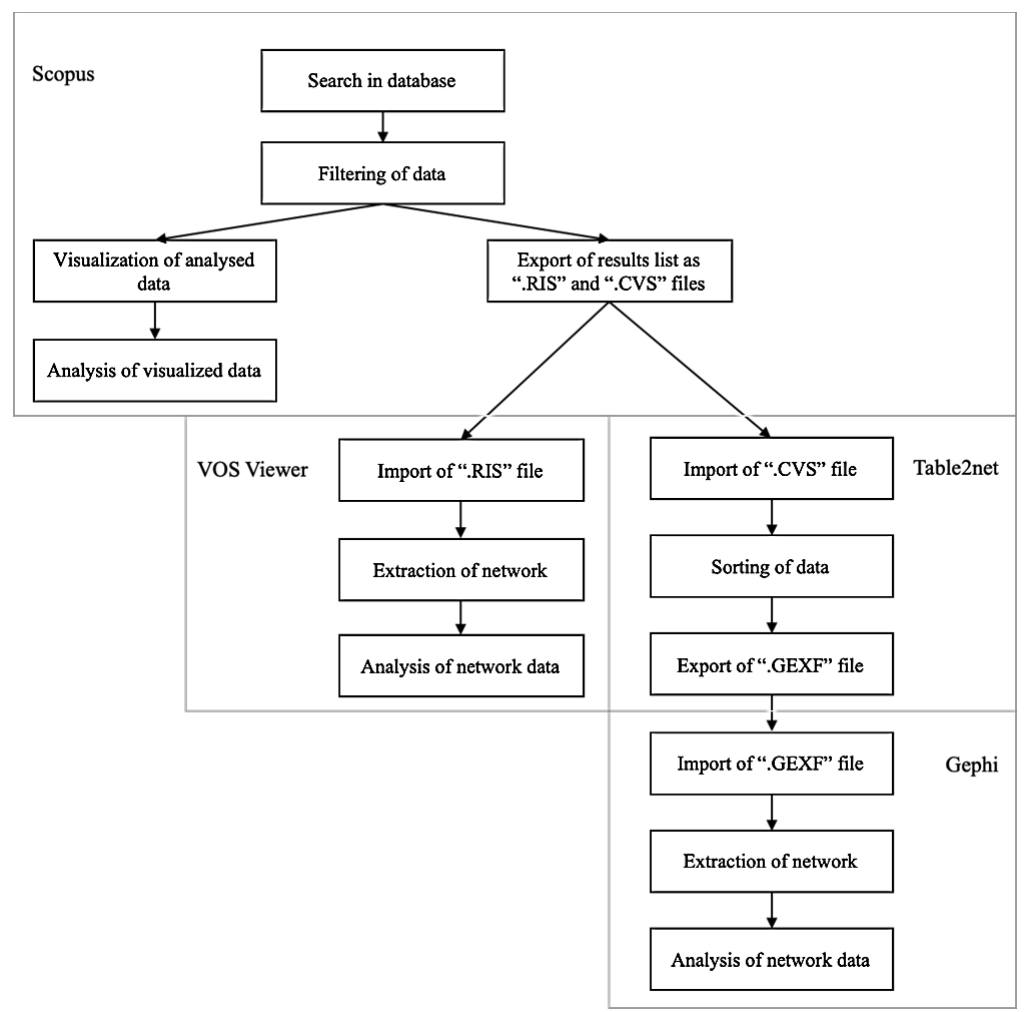

Figure 1. Procedure of bibliometric and network analysis 


\subsection{Defining the search terms}

Within the scope of this semantic search, the following keywords were defined: "organizational", "management", "development", "change", "culture", "artificial intelligence", "neuronal network". These keywords were used in word combinations: "organizational management" AND "artificial intelligence", "organizational management" AND "neuronal network", "organizational development" AND "artificial intelligence", "organizational development" AND "neuronal network", "organizational change" AND "artificial intelligence", "organizational change" AND "neuronal network", "organizational culture" AND "artificial intelligence", "organizational culture" AND "neuronal network".

To maximize the range of results, we used asterisks to include all feasible results.

The claim that the search with selected keywords covered the broad spectrum of publications is controversial. The perspectives of the scientists on this topic, as well as the meaning of definitions may vary. The search with chosen terms combinations gives an overview of the temporal evolution of the field of research and forecast future trends based only on the defined selection.

Table 1. The initial search results

\begin{tabular}{|c|c|}
\hline Search keywords & $\begin{array}{c}\text { Search } \\
\text { results } \\
\text { (no. of } \\
\text { papers) }\end{array}$ \\
\hline $\begin{array}{l}\text { "organi*ation* management" AND "artificial } \\
\text { intelligence" }\end{array}$ & 46 \\
\hline $\begin{array}{l}\text { "organi*ation* management" AND "neuronal } \\
\text { network" }\end{array}$ & 14 \\
\hline $\begin{array}{l}\text { "organi*ation* development" AND "artificial } \\
\text { intelligence" }\end{array}$ & 11 \\
\hline $\begin{array}{l}\text { "organi*ation* development" AND "neuronal } \\
\text { network" }\end{array}$ & 16 \\
\hline "organi*ation* change" AND "artificial intelligence" & 56 \\
\hline "organi*ation* change" AND "neuronal network" & 13 \\
\hline "organi*ation* culture" AND "artificial intelligence" & 43 \\
\hline "organi*ation* culture" AND "neuronal network" & 19 \\
\hline Total & 218 \\
\hline
\end{tabular}

Note: ${ }^{\star}$ varying character combinations.

\subsection{Initial data search results}

The data search was performed in the Scopus database. The defined keyword combinations were searched in titles, abstracts, and keywords of appropriate sources. The initial search resulted in 218 publications. It was stored and exported as "RIS" and ".CSV" files with such details, as paper title, author's name, year of publication, source information, affiliations, the language of an original document, abstract, keywords, sponsors, tradenames and manufacturers, references. The main part of these details was implemented in the further analyses. Table 1 shows the distribution of the search results according to keywords.

The highest quantity of publications counts 56 units and was found for all possible term combinations of "organi*ation* change" AND "artificial intelligence". That might mean that this is the most researched topic at the time of this literary analysis.

In general, all of the found publications were obtained in different subject areas. Analysis of search results on the Figure 2 highlights the proportions of scientific fields according to the quantity of publication. The largest number of publications (31\%) was published related to Computer Science area. Engineering as a subject area follows with $15.1 \%$ of publications. On the third place is Mathematics with $11.1 \%$ of search results. With the areas of Business, Management, Accounting and Social Sciences the mentioned ones amount to three quarters of all in the search involved subject areas.

This information gives us an indication of the main focus of the topic investigated.

\subsection{Refinements of the search results}

The closer inspection of initial search results reveals that a great number of publication hits belong to various nonrelevant categories. That leads to the necessity of specifying the results and elimination of these. The filtered-out parameters were commercial sources, undefined authors, as well as short publications. After refinement, the search results included conference papers, journal articles, books, and book chapters.

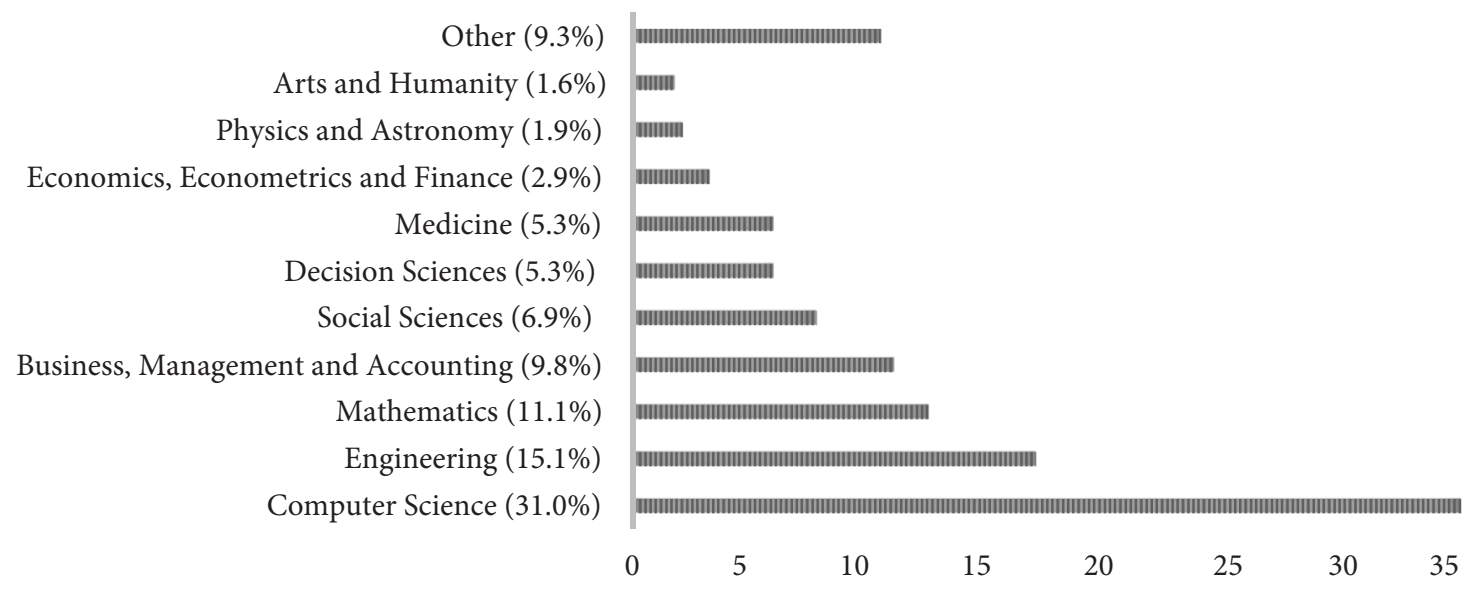

Figure 2. Pareto analysis of publications according to scientific fields 


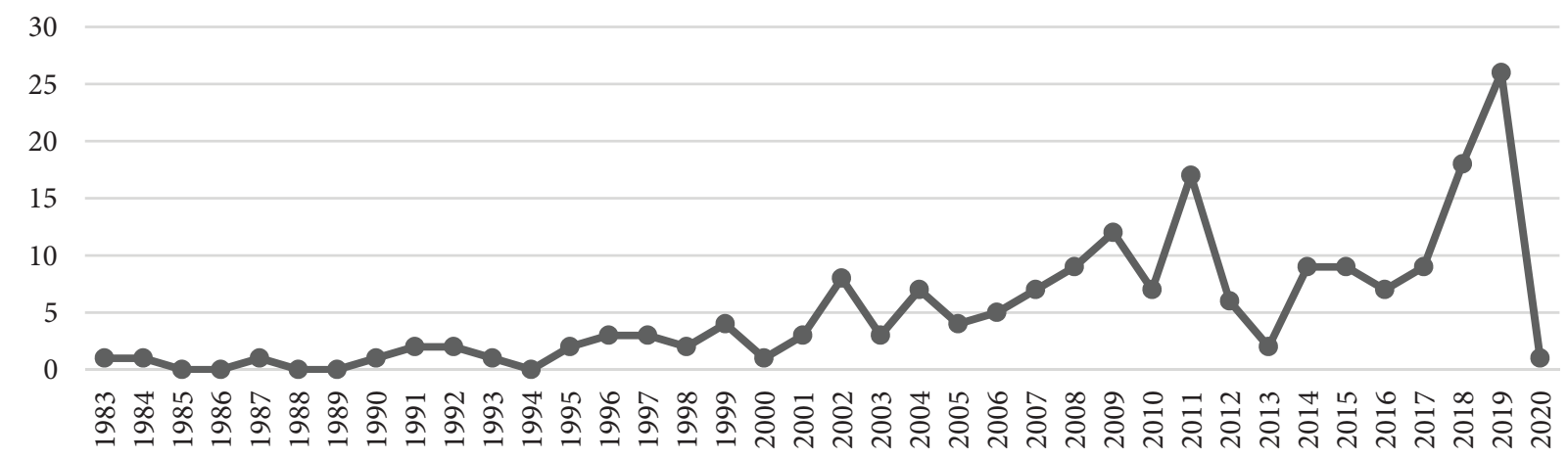

Figure 3. Publishing trend in the area of organizational management, development, change and culture, and artificial intelligence

After the refinement of equal outputs, the total sum was 191 results. The share of conference proceedings amounts to just above 57\% (109). The number of journal articles counts 78 (almost 41\%). A percentage of book chapters after refinement is 1.05 (2). The number of books has a share also of $1.05 \%$ (2). Such results distribution can be explained by the current state of technology development, which is shown in the following section by the time distribution of the publications.

\subsection{Initial data statistics}

The line graph (Figure 3) of the publication bias over the years clearly shows the uneven distribution. The largest number of papers was published after 2008, in the years 2019 (26), 2018 (18), 2011 (17) and 2009 (12). It means that the interest on the topic has recovered strongly.

The refined initial search resulted, that 72 journals published 78 articles between 1983 and 2019. This number of publications corresponds to more than the third part of the selected publications. Among the most published journals count "Computer Methods and Programs in Biomedicine", "Decision Support Systems", "International Journal of Recent Technology and Engineering", "Journal of Decision Systems", "Quality and Quantity". Each of these journals has contributed to the publication of two articles.

Almost $40 \%$ of all publications (74) are conference proceedings. 22 of them are published in:

- 2011 2nd International Conference On Artificial Intelligence Management Science And Electronic Commerce Aimsec 2011 Proceedings;

- Lecture Notes In Artificial Intelligence Subseries Of Lecture Notes In Computer Science;

- 2008 International Conference On Wireless Communications Networking And Mobile Computing Wicom 2008;

- Aaai Fall Symposium Technical Report;

- Ceur Workshop Proceedings;

- Proceedings 2009 International Conference On Computational Intelligence And Software Engineering Cise 2009;

- Proceedings Of SPIE The International Society For Optical Engineering;
- Proceedings The 11th Conference On Artificial Intelligence For Applications Caia 1995.

\section{Bibliometric analysis of publications}

The scientific analysis using bibliometric tools provides identifying the common tendencies in the publication of research achievement. On the one hand, it supports tracing the history and evolution of the thematic area; on the other hand, it quantifies the impact of different bibliometric units. We concentrated the focus of interest on the following information: authors, journal, affiliations. The extracted publications list was converted into required formats for further usage.

\subsection{Author influence}

Although the first article on the topic was published in 1983 , interest to the artificial intelligence technology in organized systems began to increase in the 2000s. This explains why even the most important authors do not have many publications in this field.

Lin W.-B. dominates with the highest number of publications (4). Cohen, M. A., Grossberg, S., Jonker, C. M. and Treur, J. follow each with three publications. The the most influenced author group includes Cohen, M. A., Grossberg, S. published 3 papers to the investigated topic, that were cited 1776 times. Three publications by Jonker, C. M., Treur, J., (Hoogendoorn, M.) were cited by 9 papers. Boer, A., Van Engers, T., (Van De Ven, S.) had published two publications, as well as the group with Bose, R., Sugumaran, V., the group with Piirto, A., Kantola, J., Vanharanta, H. (with other authors), tandem of Smits, D., Van Hillegersberg, J. and team with Vicente, H., Neves, J. (with other authors). The great majority of the most influenced authors have published in Business, Management, and Accounting as well as Computer Science areas.

\subsection{Affiliation statistics}

To achieve the regional distribution of the most important research organizations that have been explored on the topic area, we have investigated the affiliation statistics of publications. The affiliation analysis was conducted in Zotero with the data of contributing organizations, which 
were extracted from the ".RIS" file. The data was visualized in scribblemaps.com. From the Table 2 and the map on the Figure 4, the conclusion can be draw that USA seems

Table 2. Contributing of organizations based on their geographical regions

\begin{tabular}{|c|c|c|c|}
\hline $\begin{array}{l}\text { Geographical } \\
\text { position }\end{array}$ & $\begin{array}{c}\text { Number of } \\
\text { papers } \\
\text { (Percentage } \\
\text { contribution) }\end{array}$ & $\begin{array}{l}\text { Geographical } \\
\text { position }\end{array}$ & $\begin{array}{l}\text { Number } \\
\text { of papers }\end{array}$ \\
\hline \multicolumn{2}{|l|}{ America } & \multicolumn{2}{|l|}{ Europe } \\
\hline $\begin{array}{l}\text { USA } \\
\text { Canada } \\
\text { Brazil } \\
\text { Chile } \\
\text { Mexico } \\
\text { Paraguay } \\
\text { Venezuela }\end{array}$ & \begin{tabular}{|l}
$41(21.5 \%)$ \\
$6(3.1 \%)$ \\
$4(2 \%)$ \\
$1(0.5 \%)$ \\
$1(0.5 \%)$ \\
$1(0.5 \%)$ \\
$1(0.5 \%)$
\end{tabular} & $\begin{array}{l}\text { United Kingdom } \\
\text { Netherlands } \\
\text { Germany } \\
\text { Portugal } \\
\text { Romania } \\
\text { Russian Federation } \\
\text { Sweden }\end{array}$ & \begin{tabular}{|l|}
$17(9 \%)$ \\
$11(5.8 \%)$ \\
$9(4.7 \%)$ \\
$7(3.7 \%)$ \\
$7(3.7 \%)$ \\
$7(3.7 \%)$ \\
$6(3.1 \%)$
\end{tabular} \\
\hline \multicolumn{2}{|l|}{ Asia } & Italy & $5(2.6 \%)$ \\
\hline $\begin{array}{l}\text { China } \\
\text { Taiwan } \\
\text { Iran } \\
\text { South Korea } \\
\text { Japan } \\
\text { India } \\
\text { Malaysia } \\
\text { Saudi Arabia } \\
\text { Indonesia } \\
\text { Israel } \\
\text { Turkey } \\
\text { United Arab } \\
\text { Emirates } \\
\text { Armenia }\end{array}$ & \begin{tabular}{|l}
$23(12.4 \%)$ \\
$6(3.1 \%)$ \\
$5(2.6 \%)$ \\
$3(1.6 \%)$ \\
$3(1.6 \%)$ \\
$3(1.6 \%)$ \\
$2(1 \%)$ \\
$2(1 \%)$ \\
$1(0.5 \%)$ \\
$1(0.5 \%)$ \\
$1(0.5 \%)$ \\
$1(0.5 \%)$ \\
\\
$1(0.5 \%)$
\end{tabular} & $\begin{array}{l}\text { Finland } \\
\text { France } \\
\text { Spain } \\
\text { Denmark } \\
\text { Norway } \\
\text { Poland } \\
\text { Slovenia } \\
\text { Ukraine } \\
\text { Austria } \\
\text { Estonia } \\
\text { Slovakia } \\
\text { Greece } \\
\text { Montenegro } \\
\text { Belgium }\end{array}$ & $\begin{array}{l}4(2 \%) \\
3(1.6 \%) \\
3(1.6 \%) \\
2(1 \%) \\
2(1 \%) \\
2(1 \%) \\
2(1 \%) \\
2(1 \%) \\
2(1 \%) \\
1(0.5 \%) \\
1(0.5 \%) \\
1(0.5 \%) \\
1(0.5 \%) \\
1(0.5 \%)\end{array}$ \\
\hline \multicolumn{4}{|l|}{ Oceania } \\
\hline Australia & $6(3.2 \%)$ & $\begin{array}{l}\text { No affiliations in } \\
\text { Scopus records }\end{array}$ & $5(2.6 \%)$ \\
\hline
\end{tabular}

to dominate worldwide with the highest quantity of affiliation organizations (41). The pioneer in Asia is China (23) and in Europe - the United Kingdom (17). The great density of contributing organizations is in the Eastern United States, the Eastern Asia and the Western Europe.

The location of 27 most influenced contributing organizations is shown in the Table 3 . Three of them, the dominated ones, Universiteit van Amsterdam, Delft University of Technology, Vrije Universiteit Amsterdam are located in Netherlands. With University of Twente, Leibniz Center for Law the total number of publications of contributing organizations in Netherlands counts 13 . The second country with the highest number of most publicized organizations in the world is China with Central South University, Tsinghua University, Changchun University, Hebei College of Finance, North China Electric Power University (sum of publications is ten).

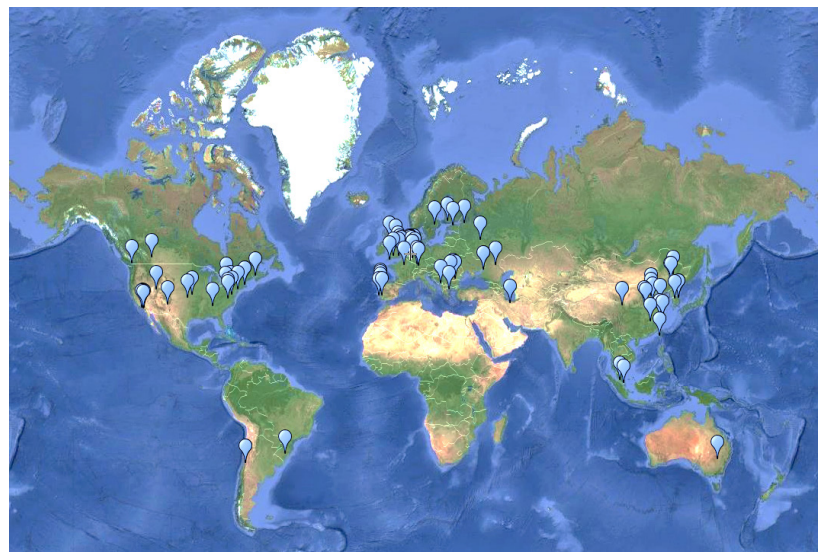

Figure 4. Geographical locations of all contributing organizations

Table 3. The top 27 contributing organizations

\begin{tabular}{|c|c|c|c|c|c|}
\hline Organization & Location & $\begin{array}{l}\text { No. of } \\
\text { papers }\end{array}$ & Organization & Location & $\begin{array}{l}\text { No. of } \\
\text { papers }\end{array}$ \\
\hline Universiteit van Amsterdam & Netherlands & 3 & University of Tehran & Iran & 2 \\
\hline Delft University of Technology & Netherlands & 3 & Waseda University & Japan & 2 \\
\hline Vrije Universiteit Amsterdam & Netherlands & 3 & Leibniz Center for Law & Netherlands & 2 \\
\hline $\begin{array}{l}\text { Rheinisch-Westfälische Technische } \\
\text { Hochschule Aachen }\end{array}$ & Germany & 3 & University of Plymouth & $\begin{array}{l}\text { United } \\
\text { Kingdom }\end{array}$ & 2 \\
\hline Universidade do Minho & Portugal & 3 & Tsinghua University & China & 2 \\
\hline National Kaohsiung Normal University & Taiwan & 3 & University of Melbourne & Australia & 2 \\
\hline Chalmers University of Technology & Sweden & 2 & University of Évora & Portugal & 2 \\
\hline The George Washington University & USA & 2 & Universitatea din Pitesti & Romania & 2 \\
\hline Tampere University of Technology & Finland & 2 & Changchun University & China & 2 \\
\hline Harvard University & USA & 2 & Teollisuuden Voima Oyj & Finland & 2 \\
\hline University of Toronto & Canada & 2 & Hebei College of Finance & China & 2 \\
\hline Central South University & China & 2 & $\begin{array}{l}\text { North China Electric Power } \\
\text { University }\end{array}$ & China & 2 \\
\hline University of Twente & Netherlands & 2 & $\begin{array}{l}\text { State University of Management, } \\
\text { Moscow }\end{array}$ & $\begin{array}{l}\text { Russian } \\
\text { Federation }\end{array}$ & 2 \\
\hline Boston University & USA & 2 & & & \\
\hline
\end{tabular}


Table 4. The most popular keywords

\begin{tabular}{|l|c|l|l|l|c|}
\hline \multicolumn{1}{|c|}{$\begin{array}{c}\text { Keyword/ Word } \\
\text { combination }\end{array}$} & Frequency & \multicolumn{1}{|c|}{$\begin{array}{c}\text { Keyword/ Word } \\
\text { combination }\end{array}$} & Frequency & \multicolumn{1}{|c|}{$\begin{array}{c}\text { Keyword/ Word } \\
\text { combination }\end{array}$} & Frequency \\
\hline Artificial Intelligence & 116 & Societies and Institutions & 18 & Management & 16 \\
\hline Decision Support Systems & 33 & Article & 17 & Management Science & 14 \\
\hline Organizational Change & 24 & Decision Making & 17 & Software Engineering & 14 \\
\hline Neural Networks & 22 & Information Systems & 17 & Information Management & 13 \\
\hline Organizational Cultures & 22 & Knowledge Management & 17 & Organizational Management & 10 \\
\hline $\begin{array}{l}\text { Organizational } \\
\text { Management }\end{array}$ & 20 & Human & 16 & Computers & 9 \\
\hline Organizational Cultures & 19 & Humans & 16 & & \\
\hline
\end{tabular}

The geographical dispersion of contributing organizations indicates that the researched topic has attracted organizations and research centers from around the globe. It has to be noted that some publications have several contributing organizations according to the author affiliation.

\section{Network analysis of keywords}

To identify new trends in the field of use of artificial intelligence technologies for organizational management, development and culture, network analysis of the keywords was executed. For this investigation from the Scopus database exported ".RIS" and ".CVS" files were used. For better sorting of data for Gephi, the publications list was imported in Table2net. Table 4 shows the most frequently used keywords. As expected, the most applied keyword is "artificial intelligence". The second one, "decision support systems", gives the hint about the function, which results from the application of artificial intelligence for organizational management, development, change and culture. The frequency of the applying of these 20 keywords crystallizes out the research focus in this area. The relationships between keywords can be recognized and analysed by network analysis. Table 5 shows that the technological focus touches on
Table 5. Top 5 most cited publications

\begin{tabular}{|l|l|}
\hline \multicolumn{1}{|c|}{ Publication } & $\begin{array}{l}\text { Interim number } \\
\text { of citations }\end{array}$ \\
\hline Cohen, M. A., Grossberg, S. (1983) & 1170 \\
Baskerville, R., Dulipovici, A. (2006) & 188 \\
Silver, M. S. (1990) & 85 \\
Lin, W.-B. (2008) & 60 \\
Lakomski, G. (2001) & 9 \\
\hline
\end{tabular}

the areas of decision making, knowledge and information management as well as human aspects.

Additionally, the searched keywords were investigated in the tool VOSViewer to detect their interconnections. The gained insights allow to observe the development of the topic and to deduce new perspectives and alternative forecasts. The result can be seen in the Figure 5. The system of linked keywords is represented as a network. The colors point to the clusters in which most of the keywords of a group occur together. The size of the node indicates the connection degree of the keywords.

As seen, the most affiliating keyword is "artificial intelligence". This is also the most connected keyword in its cluster with terms "decision making", "engineering

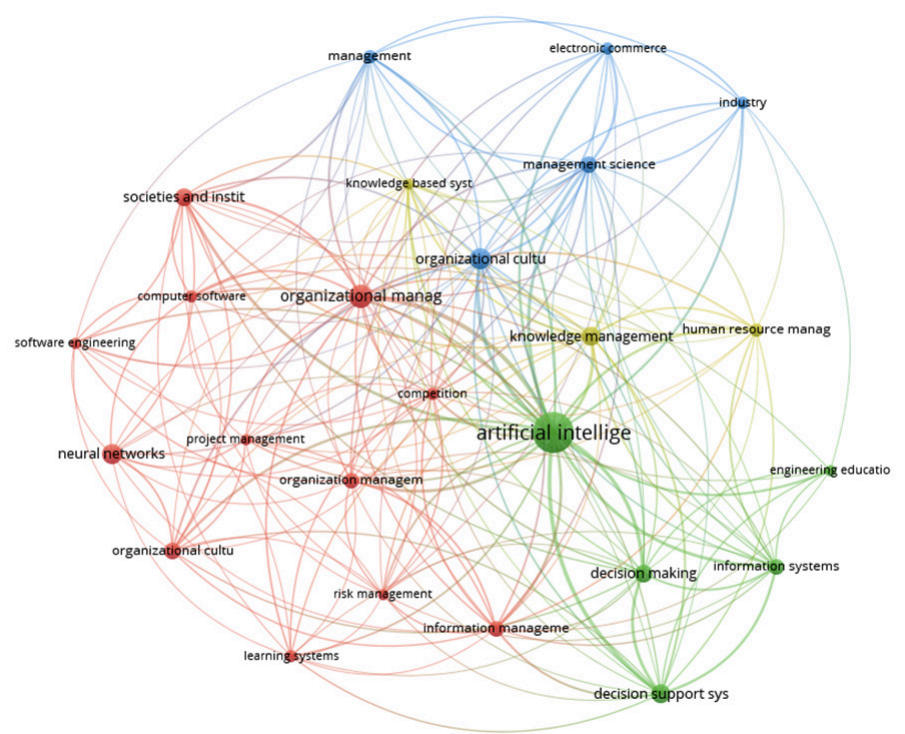

Figure 5. Network visualization of most frequent keywords 
educatio", "information systems", "decision support sys". The second largest node is the keyword "organizational manag". It is remarkable, that in comparison to the analysis by a keyword in Scopus and Zotero, the network analysis in VOSViewer shows also some other keywords as highly important (e. g. "electronic commerce", "competition"). This can be explained by the meaning of the network analysis: not the frequency but the weighting of the connections is emphasized.

\section{Network analysis of publications}

The further network analysis indicates the correlations between publications. Not only the connected objects (nodes) can be weighted, but also the connections (edges). Analysed objects may be the keywords, terms, citations, authors and others.

For network analysis and a graphical investigation was considered different open space tools, such as VOSviewer and Gephi. Gephi was chosen for this review due to its usability, appropriate functional features, such as filtering capabilities, compatibility with different data formats, and integrated network analysis tools (Bastian et al., 2009 March). Since ".CSV" format for the citations is not always displayed convenient, the files with this format have been converted to "GEXF" in Table2net.

In the section "Network analysis of keywords" we have already presented the network analysis of keywords.

\subsection{Citations analysis}

For the citations analysis was chosen an inductive approach.

The purpose of this section is to clarify the relationships between publications for better detection of unconscious or not previously recognized tendencies in the development of the research topic, as well as factors influencing scientific interest. The scientists differentiate between popularity and prestige of the paper: the first term is defined by the number of citations, the second one by the rate of citations by higher cited publications.

For visualization of citations in Gephi were used several algorithms: Force Atlas and Fruchterman Raingold, which organized the papers in clusters.

For the ranking of research, publications were used the in-degree and out-degree attributes. The in-degree attribute defines how many times the publication was cited by others. The darker the color, the more often the publication was cited.

The out-degree attribute shows the number of papers that were cited by the attribute.

The citations analysis is used to define the popularity of the publication. This approach investigates the connections between papers in the network. The citations investigation of the last 15 years (2005 till 2020) resulted the dissemination of the top 5 most cited publications, that can be seen on Table 5 .
Total h-index of the cited publications is 14 . It means that 14 results have been cited at least by 14 publications.

The citation network of the search results includes 191 nodes (papers). In the first step the initial citations analysis results, that only 19 nodes (papers) are connected to each other by 13 edges. It is above $10 \%$ percent of all papers. The low percentage of connected nodes (publications) within the network means that on the one hand the research topic has not yet been fully researched and on the other hand is firmly anchored in other research areas. This statement clarifies the network analysis of citing publications (2825).

\subsection{Network analysis of global citations}

It must be underlined that displaying local citations is different from global ones. This leads to the realization that publications with the highest global citations are used on the one hand in other areas of knowledge and at the same time have interdisciplinary knowledge.

The initial analysis of citing publications shows that the 191 publications were cited 2825 times. The most frequently entered keyword was "neural network" (compared with topic search - there "artificial intelligence"). As expected, the most investigating subject area is Computer Science. Mathematics and Engineering also take the leading positions. However, the Neuroscience has risen to fourth place, which indicates the increased scientific interest in this area.

Global citation analysis revealed that Cohen and Grossberg (1983) is the most cited publication from all search results. With 1768 citations, this publication overhauled Baskerville and Dulipovici (2006) with 188 citations and Silver (1990) with 156 citations.

The initial search results of citing publications were refined to precise the documents that match the search terms. The 107 publications were filtered out. These publications provide an overview of the related research areas, the investigation of which was possible due to the cited publications. This proves the applicability of the knowledge from the cited publications.

To obtain qualitatively better insights into the contents of the cited publications, the network analysis was conducted at Gephi. We used modularity algorithm to define the publication classes with the most significant contextual coherence (Blondel et al., 2008).

The search results were organized in 279 nodes, that were connected with 93 edges, and spreaded in 10 clusters and single nodes, which are pictured at the graph visualization on Figure 6. Each cluster is marked with the appropriate color. The larger the node, the more influential the publication is.

The research clusters have the following focuses:

1. Organizational knowledge management (i. a. its impact on software process improvement);

2. Organizational transformation of government (egovernment) and in the public sector;

3. Management of individual creativity in organizations; 


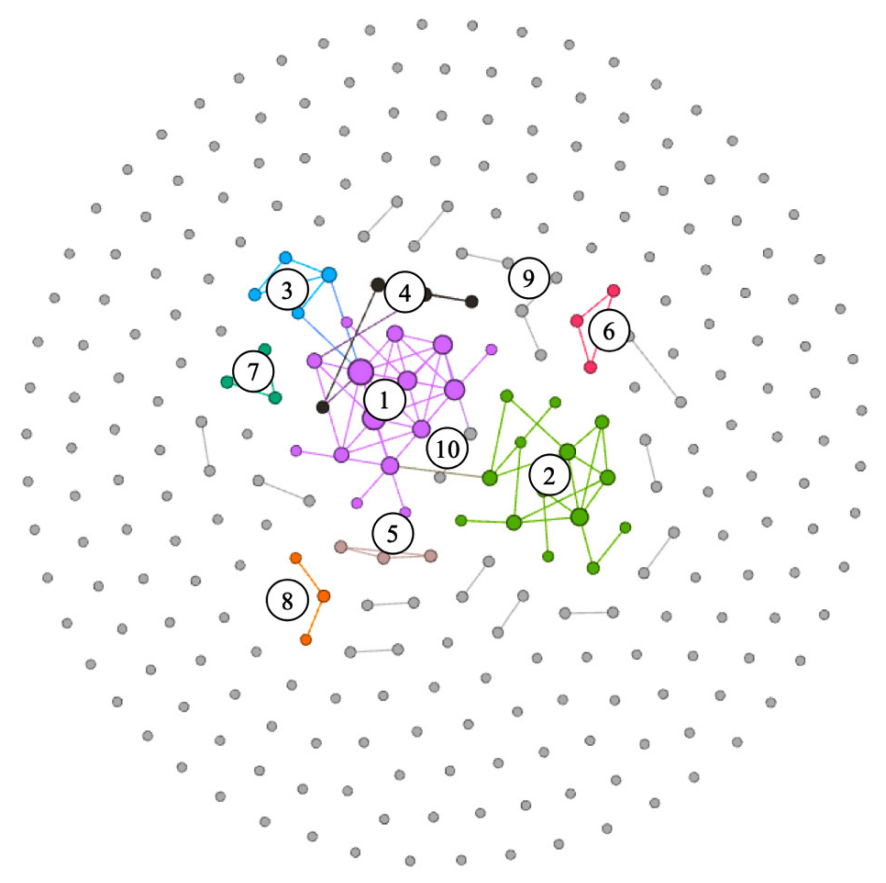

Figure 6. The layered configuration of eight clusters

4. Sustainability: of IT (environmental impact of IT technologies), with IT (decision support systems for influence of social identity in organizations for sustainability);

5. Organizational adaptivity for IoT and Big Data in health care sector, E-health;

6. Forecasting with algorithm (neural network, pattern recognition) by analysing a variety of factors (in restricted social environment, genetic disorder);

7. Fuzzy methods/applications for organizational knowledge management and culture;

8. Fundamental and conceptual studies of complexity and interactions in human (organizational) systems (methods, organizational culture, virtual enterprises);

9. Usage of artificial intelligence for different issues in health care (organizational management, medical diagnosis);

10. Decision making for change processes (health care, logistics).

The cluster analysis revealed that several clusters are coherent. Topically, the enormous share of publications related to the area of organizational knowledge management. The development of IT-supported organizational aspects in the government, public and health care sector also aroused great interest. The sensitization of organizational elements for sustainability and the support of individual creativity in organizations also attracted scientific interest. This leads us to claim that several scientists research the listed topics. Simultaneously, the potentials for those areas of knowledge, which have not yet been explored in such depth, are emerging.

Some publications in the clusters describe topics that are related neither to organizations nor to artificial intelligence technologies. The explanation for this is quite clear: many non-topic-related publications adopt approaches from other fields of knowledge in order to achieve more results that are advantageous and are based on new findings or new approaches.

The research fields of these clusters indicate new challenges for future research.

\section{Discussion}

In this article, we investigate the status quo and future development of artificial intelligence technologies for organizational management, development, change and culture using the different tools of the bibliometric and network analysis.

However, our investigation has some limitations: the search in one database, the publication time, and the using keywords. According to the first limitation, the search is restricted to the publications in only one database: the collection of the Scopus database may limit us to identifying other possible future trends, contributing organizations, and authors, as well as research areas, that can be important for further research.

The second limitation is related to the publication times, on the one hand from existing researches and on the other hand from this study: during the time a paper is published, other researches are made and newer knowledge is obtained.

The third limitation states that according to some scientists the search with used keywords can be seen as restricted due to the complexity of the topic. Further deepening of particular features and methods of organizational development, as well as less known technologies and techniques of artificial intelligence, would enrich the investigation, but at the same time would make it more complex. 


\section{Conclusions and directions for future research}

The described investigation explored the degree of reflection of development and application of technologies of artificial intelligence for organizational issues in science.

This investigation has yielded many important findings. We have found that the field of application of artificial intelligence technologies for triggering and accompanying evolutionary organizational changes, is in the formation phase. After 2000, the increase in research activity in the subject area can be observed. The chronology of publications on the topic of organizational management and development shows an improvement of the scientific interest around the year 2010 and 2019. After all, this topic remains to be explored from the social, scientific, and technological background. It is expected that in the next decade the use of artificial intelligence in the field of organizational management will gain importance and is growing all over the world. Now the USA leads in the number of publications, but the European and Asian contributing organizations have great influence.

The technological area of artificial intelligence will grow farther and will root in different spheres of our life. Although today's approaches are more focused on decision-making, knowledge management and investigation of internal organizational determinants, it is anticipated that future developments will also include the fundamentals and research results from other scientific areas.

Compared to the research organizations, companies often use new technology to achieve their own goals (strengthening resistance to competition, increasing innovation, reducing costs, etc.).

This research investigated the current state of science, highlighted the perspectives for successful implementation of the technologies of artificial intelligence in organizational management, development, change, and culture. The knowledge gained from this study can be used as input for research purposes.

In our opinion, the topic of artificial intelligence technologies in organizational management, development, technology and culture is not yet sufficiently established and cannot be fully predicted at this stage. However, the bibliometric and network investigations revealed the increasing tendency in research on this topic and the expansion of the scientific interest from other research fields.

\section{Acknowledgements}

The survey was supported by the Ministry of Education and Science of Ukraine and performed the results of the projects $0118 \mathrm{U} 003569$ and $0120 \mathrm{U} 102001$.

\section{References}

Adámek, P. (2018). The penetration of business excellence model approach and interconnection with corporate social responsibility in emerging country: A case study in the Czech Republic. International Journal of Trade and Global Markets, 11(1-2), 98-108. https://doi.org/10.1504/IJTGM.2018.092485
Akpoviroro, S. K., Amos, A. O., \& Olalekan, A. (2019). Exploring the link between competitive strategies and organizational performance in beverage industry (A case of Nestle PLC). SocioEconomic Challenges, 3(1), 116-126.

https://doi.org/10.21272/sec.3(1).116-126.2019

Atkociuniene, Z. O., \& Mikalauskiene, A. (2019). Knowledge management influence on implementing sustainable development means in the organization. Transformations in Business \& Economics, 18(3c), 546-564. http://transformations.knf. vu.lt/48c/article/know

Baskerville, R., \& Dulipovici, A. (2006). The theoretical foundations of knowledge management. Knowledge Management Research \& Practice, 4(2), 83-105. https://doi.org/10.1057/palgrave.kmrp.8500090

Bastian, M., Heymann, S., \& Jacomy, M. (2009, March). Gephi: An open source software for exploring and manipulating networks. In Third International AAAI Conference on Weblogs and Social Media (pp. 361-362). https://gephi.org/publications/gephi-bastian-feb09.pdf

Bilan, Y., Brychko, M. M., Buriak, A. V., \& Vasylieva, T. A. (2019a). Financial, business and trust cycles: The issues of synchronization. Zbornik Radova Ekonomskog Fakultet au Rijeci, 37(1), 113-138. https://doi.org/10.18045/zbefri.2019.1.113

Bilan, Y., Đšuzmenko, Đ., \& Boiko, A. (2019b). Research on the impact of industry 4.0 on entrepreneurship in various countries worldwide. In Proceedings of the 33rd International Business Information Management Association Conference (pp. 2373-2384). IBIMA.

Bilan, Y., Rubanov, P., Vasylieva, T., \& Lyeonov, S. (2019c). The influence of industry 4.0 on financial services: Determinants of alternative finance development. Polish Journal of Management Studies, 19(1), 70-93.

https://doi.org/10.17512/pjms.2019.19.1.06

Bilan, Y., Vasilyeva, T., Lyeonov, S., \& Bagmet, K. (2019d). Institutional complementarity for social and economic development. Business: Theory and Practice, 20, 103-115.

https://doi.org/10.3846/btp.2019.10

Bilan, Y., Lyeonov, S., Vasylieva, T., \& Samusevych, Y. (2018). Does tax competition for capital define entrepreneurship trends in Eastern Europe? Online Journal Modelling the New Europe, (27), 34-66. https://doi.org/10.24193/OJMNE.2018.27.02

Bilorus, T. V. (2018). Formuvannia stratehii rozvytku systemy upravlinnia personalom pidpryiemstva na osnovi portfelnoho analizu [Development strategy formation of the personnel management system of the enterprise based on portfolio analysis]. Marketing and Management of Innovations, 1, 184-195. https://doi.org/10.21272/mmi.2018.1-13

Blondel, V. D., Guillaume, J. L., Lambiotte, R., \& Lefebvre, E. (2008). Fast unfolding of communities in large networks. Journal of Statistical Mechanics: Theory and Experiment, 2008(10), P10008. https://doi.org/10.1088/1742-5468/2008/10/P10008

Bondar, T., Matvieieva, Y., \& Myroshnychenko, I. (2015). Assessment of the social, ecologic and economic development of machine building enterpris. Ekonomičnij časopis-XXI, 7-8(1), 40-44.

Borisova, A., Rakhimberdinova, M., Madiyarova, E., Riazantseva, I., \& Mikidenko, N. (2020). Staffing search and recruitment of personnel on the basis of artificial intelligence technologies. Entrepreneurship and Sustainability Issues, 7(3), 2456-2469. https://doi.org/10.9770/jesi.2020.7.3(66)

Chen, P., Xie, H., Maslov, S., \& Redner, S. (2007). Finding scientific gems with Google's PageRank algorithm. Journal of Informetrics, 1(1), 8-15.

https://doi.org/10.1016/j.joi.2006.06.001 
Cherven, K. (2015). Mastering Gephi network visualization. Packt Publishing Ltd. http://gephi.michalnovak.eu/Mastering\%20 Gephi\%20Network\%20Visualization.pdf

Cohen, M. A., \& Grossberg, S. (1983). Absolute stability of global pattern formation and parallel memory storage by competitive neural networks. IEEE Transactions on Systems, Man, and Cybernetics, 13(5), 815-826.

https://doi.org/10.1109/TSMC.1983.6313075

Egerová, D., \& Nosková, M. (2019). Top management team composition and financial performance: Examining the role of gender diversity. Business Administration and Management, 22(2), 129-143. https://doi.org/10.15240/tul/001/2019-2-009

Fryk, P., \& Iveroth, E. (2009). The emergent view of IT and organizational change. In 15th Americas Conference on Information Systems (AMCIS 2009). San Francisco, USA. https://doi.org/10.2139/ssrn.1618276

Giebe, C., Hammerström, L., \& Zwerenz, D. (2019). Big Data \& Analytics as a sustainable customer loyalty instrument in banking and finance. Financial Markets, Institutions and Risks, 3(4), 74-88. https://doi.org/10.21272/fmir.3(4).74-88.2019

Glonti, V., Trynchuk, V., Khovrak, I., Mokhonko, G., Shkrobot, M., \& Manvelidze, L. (2020). Socialization of organization sustainable development based on the principles of corporate social responsibility. Montenegrin Journal of Economics, 16(1), 169-182. https://doi.org/10.14254/1800-5845/2020.16-1.11

Grenčíková, A., Bilan, Y., Samusevych, Y., \& Vysochyna, A. (2019). Drivers and inhibitors of entrepreneurship development in central and eastern European countries. In Proceedings of the 33rd International Business Information Management Association Conference (pp. 2536-2547). IBIMA.

Grytsenko, L. L., Boyarko, I. M., \& Gubar, A. A. (2009). Discriminant model of small enterprises' bankruptcy diagnostics. Actual Problems of Economics, (95), 256-262.

Grytsenko, L. L., Boyarko, I. M., \& Roenko, V. V. (2010). Controlling of enterprises cash flows. Actual Problems of Economics, (105), 148-154.

Hadbaa, H., \& Boutti, R. (2019). Behavioral biases influencing the decision making of portfolio managers of capital securities and traders in Morocco. Financial Markets, Institutions and Risks, 3(1), 92-105.

https://doi.org/10.21272/fmir.3(1).92-105.2019

Hammerström, L., Giebe, C., \& Zwerenz, D. (2019). Influence of Big Data \& analytics on corporate social responsibility. SocioEconomic Challenges, 3(3), 47-60. https://doi.org/10.21272/ sec.3(3).47-60.2019

Hasan, M. M., Hossain, A., \& Khan, Y. H. (2018). Factors persuading female participation towards entrepreneurial activities and its impact on employment creation. SocioEconomic Challenges, 3(2), 49-58.

https://doi.org/10.21272/sec.3(2).49-58.2018

Hong-Ngam, J. (2018). Earnings and engagement of seamen workers. International Journal of Economic Policy in Emerging Economies, 11(1-2), 114-123. https://doi.org/10.1504/ IJEPEE.2018.091030

Hoogendoorn, M., Jonker, C. M., \& Treur, J. (2006, August). Redesign of organizations as a basis for organizational change. In AAMAS 2006 and ECAI 2006 International Workshops on Coordination, Organizations, Institutions, and Norms in Agent Systems II, Vol. 4386 of LNAI (pp. 48-64). Springer. https://link. springer.com/content/pdf/10.1007\%2F978-3-540-74459-7.pdf

Hrytsenko, L. L., \& Isayeva, O. V. (2011). Approaches to classification of forms and types of enterprise restructuring. Actual Problems of Economics, (118), 111-116.

Idzikowski, W., \& Perechuda, I. (2018). Agile approach in a transforming organization, a descriptive study of chosen Pol- ish companies with rapid revenue growth. Oeconomia Copernicana, 9(3), 461-475. https://doi.org/10.24136/oc.2018.023

Kaasa, A. (2019). Determinants of individual-level social capital: Culture and personal values. Journal of International Studies, 12(1), 9-32. https://doi.org/10.14254/2071-8330.2019/12-1/1

Karpishchenko, O. I., Peresadko, G. O., \& Olefirenko, O. M. (2014). Enterprise management systems: the case of Primary Radiology Group. Actual Problems of Economics, (4), 218-227.

Kashyap, R. N. (1972). Management information systems for corporate planning and control. Long Range Planning, 5(2), 25-31. https://doi.org/10.1016/0024-6301(72)90042-8

Kendiukhov, I., \& Tvaronaviciene, M. (2017). Managing innovations in sustainable economic growth. Marketing and Management of Innovations, (3), 33-42.

https://doi.org/10.21272/mmi.2017.3-03

Khan, Y. (2018). Strategic human resource practices and its impact on performance towards achieving organizational goals. Business Ethics and Leadership, 2(2), 66-73. https://doi.org/10.21272/bel.2(2).66-73.2018

Kosch, O., \& Szarucki, M. (2020). Transatlantic affiliations of scientific collaboration in strategic management: A quartercentury of bibliometric evidence. Journal of Business Economics and Management, 21(3), 627-646. https://doi.org/10.3846/jbem.2020.12395

Kowo, S. A., Kadiri, B. I., \& Zekeri, A. (2020). Correlate of workforce diversity and organisational performance of multinational food producing industry in Nigeria. Business Ethics and Leadership, 4(1), 126-137. https://doi.org/10.21272/bel.4(1).126-137.2020

Kvitka, S., Starushenko, G., Kovalenko, V., Deforzh, H., \& Prokopenko, O. (2019). Marketing of Ukrainian higher educational institutions representation based on modeling of Webometrics Ranking. Marketing and Management of Innovations, (3), 60-72. https://doi.org/10.21272/mmi.2019.3-05

Lakomski, G. (2001). Organizational change, leadership and learning: Culture as cognitive process. International Journal of Educational Management, 15(2), 68-77.

https://doi.org/10.1108/09513540110383791

Lee, J. Y., \& Lee, Y. M. (2018). An exploratory study on employee assistance program for career development counselling. International Journal of Economic Policy in Emerging Economies, 11(1-2), 100-113. https://doi.org/10.1504/IJEPEE.2018.091031

Lin, W. B. (2008). The effect of knowledge sharing model. Expert Systems with Applications, 34(2), 1508-1521.

https://doi.org/10.1016/j.eswa.2007.01.015

Lyeonov, S., \& Liuta, O. (2016). Actual problems of finance teaching in Ukraine in the post-crisis period. In The Financial Crisis (pp. 145-152). Springer.

https://doi.org/10.1007/978-3-319-20588-5_8

Lyulyov, O., \& Shvindina, H. (2017). Stabilization Pentagon Model: application in the management at macro-and microlevels. Problems and Perspectives in Management, 15(3), 4252. https://doi.org/10.21511/ppm.15(3).2017.04

Lušňáková, Z., Juríčková, Z., Šajbidorová, M., \& Lenčéšová, S. (2019). Succession as a sustainability factor of family business in Slovakia. Equilibrium. Quarterly Journal of Economics and Economic Policy, 14(3), 503-520. https://doi.org/10.24136/eq.2019.024

Madani, M., \& Rungsrisawat, S. (2019). The knowledge sharing and the relationship between efficient team and supply chain management. Polish Journal of Management Studies, 20(1), 254-266. https://doi.org/10.17512/pjms.2019.20.1.23 
Machova, R., Kosar, S. T., \& Hevesi, A. (2018). Management and motivation of human resources in case of a Slovak multinational corporation. Marketing and Management of Innovations, (3), 174-185. https://doi.org/10.21272/mmi.2018.3-15

Mihalčová, B., Gallo, P., \& Štofová, L. (2018). Gender stereotypes at managerial positions in selected public institution. Administration \& Public Management Review, (30), 96-108. https://doi.org/10.24818/amp/2018.30-07

Mihardjo, L. W. W., \& Sasmoko, R. R. (2019). Customer experience and organizational agility driven business model innovation to shape sustainable development. Polish Journal of Management Studies, 20(1), 293-304. https://doi.org/10.17512/pjms.2019.20.1.26

Mikelsone, E., Spilbergs, A., Volkova, T., \& Liela, E. (2020). Idea management system application types in local and global context. Equilibrium. Quarterly Journal of Economics and Economic Policy, 15(1), 151-166. https://doi.org/10.24136/eq.2020.008

Minasyan, D., \& Tovmasyan, G. (2020). Gender differences in decision-making and leadership: Evidence from Armenia. Business Ethics and Leadership, 4(1), 6-16. https://doi.org/10.21272/bel.4(1).6-16.2020

Myroshnychenko, I., Makarenko, I., Smolennikov, D., \& Buriak, A. (2019). The approach to managing corporate social and environmental responsibility in manufacturing. TEM Journal, 8(3), 740-748.

Nguyen, T. T. N., \& Luu, T. M. N. (2019). Linking Transformational leadership and organizational performance: an empirical investigation of manufacturing firms in Vietnam. Economics \& Sociology, 12(2), 170-191.

https://doi.org/10.14254/2071-789X.2019/12-2/10

Njegovanović, A. (2018). Digital financial decision with a view of neuroplasticity/neurofinancy/neural networks. Financial Markets, Institutions and Risks, 2(4), 82-91.

https://doi.org/10.21272/fmir.2(4).82-91.2018

Nunes, F. G., Martins, L., \& Mozzicafreddo, J. (2018). The influence of service climate, identity strength, and contextual ambidexterity upon the performance of public organizations. Administratie si Management Public, (31), 6-20.

Oladimeji, M. S., \& Udosen, I. (2019). The effect of diversification strategy on organizational performance. Journal of Competitiveness, 11(4), 120-131.

https://doi.org/10.7441/joc.2019.04.08

Olefirenko, O. M., Nagornyi, Y. I., \& Shevliuga, O. G. (2014). Methodical approach to estimation of industrial enterprises technical and technological development level. Actual Problems of Economics, (8), 464-470.

Pakhnenko, O., Liuta, O., \& Pihul, N. (2018). Methodological approaches to assessment of the efficiency of business entities activity. Business and Economic Horizons (BEH), 14(1), 143-151. https://doi.org/10.15208/beh.2018.12

Pham, N. T., Tučková, Z., \& Phan, Q. P. T. (2019). Greening human resource management and employee commitment toward the environment: an interaction model. Journal of Business Economics and Management, 20(3), 446-465. https://doi.org/10.3846/jbem.2019.9659

Peresadko, G. O., Kovalenko, E. V., \& Kulyk, L. A. (2014). Mechanisms of investing into innovative projects of enterprises. Actual Problems of Economics, (10), 184-187.

Polyanska, A., Zapukhliak, I., \& Diuk, O. (2019). Culture of organization in conditions of changes as an ability of efficient transformations: the case of gas transportation companies in Ukraine. Oeconomia Copernicana, 10(3), 561-580.

https://doi.org/10.24136/oc.2019.027
Pudjiarti, E. S., \& Hutomo, P. T. P. (2020). Innovative work behaviour: an integrative investigation of person-job fit, personorganization fit, and person-group fit. Business: Theory and Practice, 21(1), 39-47. https://doi.org/10.3846/btp.2020.9487

Rachida, A. (2020). Digitalization for human resource management. Marketing and Management of Innovations, 1, 245-255. https://doi.org/10.21272/mmi.2020.1-20

Ryabenkov, O. V., \& Vasyliyeva, T. A. (2013). Comprehensive approach to application of financial controlling methods in the context of efficient application of profitability potential. Actual Problems of Economics, 148(10), 160-165.

https://eco-science.net/downloads/

Savytska, N., Chmil, H., Hrabylnikova, O., Pushkina, O., \& Vakulich, M. (2019). Behavioral models for ensuring the security of functioning and organizational sustainability of the enterprise. Journal of Security \& Sustainability Issues, 9(1), 64-76. https://doi.org/10.9770/jssi.2019.9.1(6)

Senyo, P. K., Liu, K., \& Effah, J. (2019). Digital business ecosystem: Literature review and a framework for future research. International Journal of Information Management, 47, 52-64. https://doi.org/10.1016/j.ijinfomgt.2019.01.002

Serhii, I., Peresadko, G., Pidlisna, O., \& Kovalenko, E. (2014). Corporate social responsibility in marketing researches: Literature review. Corporate Ownership \& Control, 11(4-5), 499-503. https://doi.org/10.22495/cocv11i4c5p8

Shvindina, H. (2019). Coopetition as an emerging trend in research: perspectives for safety \& security. Safety, 5(3), 61. https://doi.org/10.3390/safety5030061

Silver, M. S. (1990). Decision support systems: directed and nondirected change. Information Systems Research, 1(1), 47-70. https://doi.org/10.1287/isre.1.1.47

Sirbu, M., \& Simion, D. M. (2018). Contextualization of management practices from the perspective of knowledge-based management. Transformations in Business \& Economics, $17(3), 125-139$.

Skačkauskienė, I., Hrušecká, D., Katinienè, A., \& Čepel, M. (2018). Evaluation of knowledge synergy components. $E$ a M: Ekonomie a Management, 21(1), 144-158. https://doi.org/10.15240/tul/001/2018-1-010

Skliar, I. D., \& Samoilikova, A. V. (2014). Risk evaluation at enterprise innovation and investment activity financing. Actual Problems of Economics, 161(11), 173-178.

Smits, D., \& van Hillegersberg, J. (2014, September). The development of an IT governance maturity model for hard and soft governance. In 8th European Conference on IS Management and Evaluation, ECIME 2014 (pp. 347-355). Academic Conferences and Publishing International Limited.

Stacho, Z., Stachová, K., \& Raišienè, A. G. (2019). Change in approach to employee development in organizations on a regional scale. Journal of International Studies, 12(2), 299-308. https://doi.org/10.14254/2071-8330.2019/12-2/19

Strielkowski, W., \& Chigisheva, O. (2018). Research functionality and academic publishing: gaming with altmetrics in the digital age. Economics \& Sociology, 11(4), 306-316. https://doi.org/10.14254/2071-789X.2018/11-4/20

Syhyda, L. (2013). Influence of enterprise's marketing environment on process of marketing distribution policy development. Economic Annals-XXI, 7-8(2), 28-32.

http://soskin.info/en/ea/2013/7-8/contents_36.html

Suyono, J., Sawitri, H. S. R., Sunaryo, S., Mansur, A. S., \& Risgiyanti. (2020). Follower characteristics, obedience, and constructive resistance: The role of co-production leadership. International Journal of Trade and Global Markets, 13(2), 182-198. https://doi.org/10.1504/IJTGM.2020.106752 
Teletov, A., Teletova, S., \& Letunovska, N. (2019). Use of language games in advertising texts as a creative approach in advertising management. Periodicals of Engineering and Natural Sciences, 7(2), 458-465. https://doi.org/10.21533/pen.v7i2.569

Thabhiranrak, T., \& Jermsittiparsert, K. (2019). Towards sustainable functioning of organization: women empowernment and corporate management culture. Journal of Security \& Sustainability Issues, 9(1), 321-332. https://doi.org/10.9770/jssi.2019.9.1(24)

Tielietov, O. S., \& Letunovska, N. Y. (2014). Organizational and economic mechanism of industrial enterprises social infrastructure management. Actual Problems of Economics, 160(10), 329-337.

Titko, J., Svirina, A., Skvarciany, V., \& Shina, I. (2020). Values of young employees: Z-generation perception. Business: Theory and Practice, 21(1), 10-17. https://doi.org/10.3846/btp.2020.11166

Utami, W., Tobing, D. S. K., Paramu, H., \& Slamin, S. (2019). Expatriate career development: Self efficacy, multicultural personality, collective efficacy, and individual expatriate performance. International Journal of Trade and Global Markets, 12(2), 187-198. https://doi.org/10.1504/IJTGM.2019.100352

Van Eck, N. J., \& Waltman, L. (2017a, October 23). VOS Viewer Manual. Universiteit Leiden. https://www.vosviewer.com/ documentation/Manual_VOSviewer_1.6.6.pdf

Van Eck, N. J., \& Waltman, L. (2017b). Citation-based clustering of publications using CitNetExplorer and VOSviewer. Scientometrics, 111(2), 1053-1070. https://doi.org/10.1007/s11192-017-2300-7

Vasilieva, T. A., Lieonov, S. V., Makarenko, I. O., \& Sirkovska, N. (2017). Sustainability information disclosure as an instrument of marketing communication with stakeholders: Markets, social and economic aspects. Marketing and Management of Innovations, (4), 350-357.

https://doi.org/10.21272/mmi.2017.4-31
Vasilyeva, T., Kuzmenko, O., Bozhenko, V., \& Kolotilina, O. (2019). Assessing the dynamics of bifurcation transformations in the economy. In SHS Web of Conferences, 65, 04006. EDP Sciences. https://doi.org/10.1051/shsconf/20196504006

Wysokińśka-Senkus, A. (2020). The model of an organization performance measurement in the context of sustainable system management. Entrepreneurship and Sustainability Issues, 7(3), 1819-1831. https://doi.org/10.9770/jesi.2020.7.3(25)

Yevdokimova, M., Zamlynskyi, V., Minakova, S., Biriuk, O., \& Ilina, O. (2019). Evolution of corporate social responsibility applied to the concept of sustainable development. Journal of Security \& Sustainability Issues, 8(3), 473-480. https://doi.org/10.9770/jssi.2019.8.3(14)

Zakharkina, L. S. (2009). Balancing of innovative development of machine-building enterprises in strategic planning process. Actual Problems of Economics, (93), 88-95.

Zakharkin, O. O. (2014). Value-based management on the basis of stakeholder approach within the bounds of innovative development enterprise. Actual Problems of Economics, 160(1), 149-157. https://eco-science.net/downloads/

Zakharkin, O. O., Basantsov, I. V., \& Myroshnychenko, I. O. (2019). Analysis of the innovative development directions for industrial enterprises. Revista ESPACIOS, 40(27). http://www. revistaespacios.com/a19v40n27/a19v40n27p16.pdf

Zakharkin, O., \& Zakharkina, L. (2014). Enterprise's innovation development strategy substantiation and its aims. Economic Annals-XXI, 7-8(1), 76-79. http://soskin.info/userfiles/ file/2014/7-8_2014/7-8_1/Zakharkin\%20Zakharkina.pdf

Žitkiene, R., \& Deksnys, M. (2018). Organizational agility conceptual model. Montenegrin Journal of Economics, 14(2), 115129. https://doi.org/10.14254/1800-5845/2018.14-2.7 